\title{
NADPH-Cytochrome P450 Reductase Mediates the Resistance of Aphis (Toxoptera) citricidus (Kirkaldy) to Abamectin
}

\section{OPEN ACCESS}

Edited by:

Arash Zibaee,

University of Gilan, Iran

Reviewed by:

Jose Eduardo Serrão,

Universidade Federal de Viçosa, Brazil

Rui Pang,

Guangdong Institute of Microbiology (CAS), China

*Correspondence:

Jin-Jun Wang

jjwang7008@yahoo.com;

wangjinjun@swu.edu.cn

Specialty section:

This article was submitted to

Invertebrate Physiology,

a section of the journa

Frontiers in Physiology

Received: 23 April 2018

Accepted: 05 July 2018

Published: 10 August 2018

Citation:

Jing T-X, Tan Y, Ding B-Y, Dou W,

Wei D-D and Wang J-J (2018)

NADPH-Cytochrome P450

Reductase Mediates the Resistance

of Aphis (Toxoptera) citricidus

(Kirkaldy) to Abamectin.

Front. Physiol. 9:986.

doi: 10.3389/fphys.2018.00986
Tian-Xing Jing ${ }^{1,2}$, Yang Tan ${ }^{1,2}$, Bi-Yue Ding ${ }^{1,2}$, Wei Dou ${ }^{1,2}$, Dan-Dan Wei, ${ }^{1,2}$ and Jin-Jun Wang ${ }^{1,2 *}$

1 Key Laboratory of Entomology and Pest Control Engineering, College of Plant Protection, Southwest University, Chongqing, China, ${ }^{2}$ Academy of Agricultural Sciences, Southwest University, Chongaing, China

$\mathrm{NADPH}$-cytochrome P450 reductase (CPR) plays an essential role in the cytochrome P450 enzyme system, which aids in the metabolism of endogenous and exogenous compounds including the detoxification of insecticides. In this study, the CPR transcript in Aphis (Toxoptera) citricidus (Kirkaldy) was cloned, and the deduced amino acid sequence contained an $\mathrm{N}$-terminal membrane anchor, three conserved binding domains (flavin mononucleotide, flavin adeninedinucleotide, and nicotinamide adenine dinucleotide phosphate), a flavin adeninedinucleotide-binding motif, and catalytic residues. Based on phylogenetic analysis, AcCPR was grouped in the hemipteran branch. AcCPR was ubiquitously expressed at all developmental stages and was most abundant in the adults and least abundant in third instar nymphs. Compared with other tested tissues of adults, the expression level of AcCPR was significantly high in the gut. Feeding double-stranded RNA of AcCPR reduced the AcCPR mRNA level and the activity of AcCPR in aphids, and the treated insects exhibited higher susceptibility to abamectin than the control group. Furthermore, the heterologous overexpression of AcCPR in Sf9 cells resulted in a greater viability than control cells when treated with abamectin. All results demonstrated that AcCPR may contribute to the resistance of A. citricidus to abamectin, and CPR may be a potential target for novel insecticide design or a new factor in the development of insecticide resistance.

Keywords: NADPH-cytochrome P450 reductase, Aphis citricidus, abamectin, heterologous expression, insecticide resistance

\section{INTRODUCTION}

The brown citrus aphid, Aphis (Toxoptera) citricidus (Kirkaldy), is an important citrus pest with a global presence and is the most important vector of the Citrus tristeza virus (CTV) within its distribution area. The citrus trees can be directly damaged by the sap feeding of A. citricidus and the transmission of CTV by the brown citrus aphid can cause the most damage (Hunter et al., 2003; Moreno et al., 2008). Abamectin, a commonly used insecticide, belongs to the avermectin subfamily of macrocyclic lactones (Burg et al., 1979). It is used against major agricultural pests and insects that threaten public health (Lasota and Dybas, 1991; Shoop et al., 1995). It is also widely used to control pest in citrus groves. Therefore, several pest species have developed severe resistance to this insecticide (Liao et al., 2016). 
Cytochrome P450 monooxygenase (P450), ubiquitous in all living organisms including insects, is one of the largest super families and plays a key role in the detoxification of xenobiotics such as plant toxins, pesticides, drugs, and mutagens (Feyereisen, 1999). Most biological reactions catalyzed by microsomal $\mathrm{P} 450$ s requires an integral enzyme, NADPHcytochrome P450 reductase (CPR) (Paine et al., 2005). In general, each insect species has only one $C P R$ transcript, and the CPR protein is thought to be a fusion of two ancestral proteins, a flavin mononucleotide (FMN)-containing flavodoxin and a flavin adeninedinucleotide (FAD)-containing reductase. Therefore, $\mathrm{CPR}$ has an $\mathrm{N}$-terminal transmembrane region and the three conserved domains, FMN-, FAD-, and nicotinamide adenine dinucleotide phosphate (NADP)-binding domains (Wang et al., 1997). CPR accepts the hydride ion from NADPH and then transfers electrons to FMN. The step finally reduces the P450 enzyme heme center and activates molecular oxygen (Niu et al., 2017). To date, over 30 CPRs have been identified from insects and most of them are involved in insecticide resistance such as the CPRs from Bactrocera dorsalis (Huang et al., 2015), Laodelphax striatellus (Zhang et al., 2016), and Locusta migratoria (Zhang et al., 2017).

In the present study, we cloned and characterized the $C P R$ gene from $A$. citricidus. Expression patterns of $A c C P R$ in developmental stages and various tissues were examined by real-time quantitative PCR (RT-qPCR). Using RNA interference (RNAi) to knockdown the expression of $A c C P R$, the susceptibility of $A$. citricidus to abamectin was tested. In combination with heterologous expression and cytotoxicity assays in Sf9 cells, the function of $A c C P R$ on abamectin tolerance was determined. Our data provided some basic information about CPR in $A$. citricidus and elucidated the roles of CPR in the resistance of this aphid to abamectin.

\section{MATERIALS AND METHODS}

\section{Insect Culture}

The stock colony of $A$. citricidus was originally collected at adult stage from a wild population of aphid in a screen house (Southwest University, Chongqing, China) in 2012. This colony was maintained on potted citrus seedlings (Citrus sinensis) in the laboratory at $25 \pm 1{ }^{\circ} \mathrm{C}$, with $75-80 \%$ relative humidity and a 14 : 10-h (light: dark) photoperiod.

\section{Sample Preparation}

The aphids used for detecting the relative quantity of $A c C P R$ in different developmental stages included the first, second, third (wingless and winged), fourth (wingless and winged) instar nymphs, adults (2-d-old apterous and alate aphids after the final molt), and various adult tissues. The tissues from adult aphids were dissected at $4^{\circ} \mathrm{C}$ in $0.01 \mathrm{M}$ phosphate buffer saline (PBS). The central nervous system of aphids was dissected from 200 individuals, embryos from 50 individuals, fat bodies from 100 individuals, integuments from 50 individuals, guts from 100 individuals, and salivary glands from 200 individuals, respectively. The adult aphids were used to conduct the RNAi experiment. Four biological replicates were used for all sample preparations. All samples used for RNA extraction were stored in TRIzol reagent (Life Technologies, CA, United States) and frozen at $-80^{\circ} \mathrm{C}$ before use.

\section{Cloning of AcCPR}

Total RNA of the collected aphid samples was isolated using TRIzol reagent (Life Technologies) and the first-single-strand cDNA was prepared using the PrimerScript ${ }^{\mathrm{TM}}$ RT Reagent Kit (TaKaRa Bio, Dalian, China) according to the manufacturer's protocol. The open reading frame (ORF) of AcCPR was cloned using the primers (Supplementary Table S1) that were designed based on the data of $A$. citricidus transcriptome. PCR was carried out using PrimeSTAR ${ }^{\circledR}$ Max DNA Polymerase (TaKaRa Bio, Dalian, China). The PCR cycling conditions were as follows: $98^{\circ} \mathrm{C}$ for $3 \mathrm{~min} ; 35$ cycles $\left(98^{\circ} \mathrm{C}\right.$ for $15 \mathrm{~s}, 58^{\circ} \mathrm{C}$ for $15 \mathrm{~s}, 72^{\circ} \mathrm{C}$ for $2 \mathrm{~min}$ ); and $72^{\circ} \mathrm{C}$ for $10 \mathrm{~min}$. The amplified DNA was purified and ligated into the pGEM-T Easy Vector (Promega, Madison, WI, United States). Positive clones were verified by PCR using the universal primers M13F and M13R and sequenced (Invitrogen, Shanghai, China).

\section{Bioinformatics Analysis of the AcCPR Gene}

DNAMAN v.6.03 (Lynnon Biosoft, San Ramon, CA, United States) software was used to obtain the deduced amino acid sequence of AcCPR and the ExPASy Proteomics Server ${ }^{1}$ was used to compute the molecular weight and isoelectric point of AcCPR. Conserved domains were predicted using the Conserved Domains Database ${ }^{2}$. The transmembrane helices were predicted using the TMHMM Server v. $2.0^{3}$. A phylogenetic tree was constructed based on amino acid sequences by the neighbor-joining (NJ) method with 1,000 bootstrap replicates using the MEGA 6.0 (Tamura et al., 2013).

\section{Quantitative Real-Time PCR (RT-qPCR)}

Specific primers (Supplementary Table S1) designed on PRIMER $3.0^{4}$ were used in RT-qPCR, and the parameters of these primers (efficiency and determination coefficient) were established and calculated. The Bio-Rad CFX Connect ${ }^{\mathrm{TM}}$ real-time PCR system was used to perform the RT-qPCR, and this $20 \mu \mathrm{L}$-volume system contains $2 \times$ SYBR Green Real-time PCR Master Mix $(10 \mu \mathrm{L})$, template $(1 \mu \mathrm{L})$, each RT-qPCR primer $(1 \mu \mathrm{L})$, and DNase-free water $(7 \mu \mathrm{L})$. The reaction included an initial $120 \mathrm{~s}$-incubation at $98^{\circ} \mathrm{C}$, then 40 cycles $\left(95^{\circ} \mathrm{C}\right.$ for $30 \mathrm{~s}, 60^{\circ} \mathrm{C}$ for $\left.30 \mathrm{~s}\right)$, a step of $60^{\circ} \mathrm{C}$ for $30 \mathrm{~s}$, and the final step of $95^{\circ} \mathrm{C}$ for $30 \mathrm{~s}$. Two reference genes, elongation factor-1alpha, and beta actin were used to normalize the levels of $A c C P R$ by qBase (Hellemans et al., 2007; Shang et al., 2015).

\footnotetext{
${ }^{1}$ http://cn.expasy.org/tools/pi_tool.html

${ }^{2}$ http://www.ncbi.nlm.nih.gov/cdd

${ }^{3} \mathrm{http}: / /$ www.cbs.dtu.dk/services/TMHMM/

${ }^{4}$ http://bioinfo.ut.ee/primer3-0.4.0/
} 


\section{Silencing of AcCPR by RNAi}

The dsRNA primers (Supplementary Table S1) were used to perform PCR reaction to obtain the DNA templates for dsRNA synthesis. The purified DNA templates were then used to synthesize dsRNA according to the TranscriptAid T7 High Yield Transcription Kit (Thermo Scientific, Wilmington, DE, United States).

The AcCPR transcript in aphids was knocked down by feeding $d s C P R$ through citrus leaves as the description of previous studies in our laboratory (Ding et al., 2017; Shang et al., 2017). Briefly, a citrus stem apex (about $8-\mathrm{cm}$ long) was inserted into a $d s C P R$ containing PCR tube. Then, 25 adult aphids were released onto the citrus stem apex. This $d s C P R$-containing PCR tube with released aphids was moved into a $50-\mathrm{mL}$ plastic tube. The expression level of $A c C P R$ was detected after a 24-h dsRNA treatment. Aphids on citrus leaves containing $d s G F P$ or PBS were used as controls.

\section{Bioassays With Abamectin After RNAi}

To determine the susceptibility of aphids to abamectin after gene silencing, abamectin was dissolved in acetone $(2.5 \mathrm{mg} / \mathrm{L}$, corresponding to $\mathrm{LC}_{50}$ of abamectin against brown citrus aphid) and 20 aphids subjected to a $24 \mathrm{~h}$ dsRNA treatment were immersed in the abamectin solution for $5 \mathrm{~s}$. After exposure, all the treated aphids were transferred to fresh citrus leaves and maintained under normal rearing conditions. Mortality was determined at $12 \mathrm{~h}$ after abamectin exposure. The aphids showing no response or with irregularly shuddering legs were considered as dead. The experiments were repeated four times.

\section{Heterologous Expression of AcCPR in Sf9 Cells}

The AcCPR protein was obtained using the Bac-to-Bac ${ }^{\oplus}$ baculovirus expression system (Invitrogen). Briefly, the $A c C P R$ ORF was subcloned into the pFastBac HT A vector at the BamHI/XbaI cloning sites. The AcCPR-HTA bacmid was transformed into DH10Bac competent Escherichia coli to obtain the recombinant expression bacmid. Then Sf9 cells (Life Technologies) were transfected by recombinant expression bacmid DNA to produce baculovirus stock. A total of $25 \mathrm{~mL}$ Sf9 cells were infected with baculovirus, harvested after infection $(72 \mathrm{~h})$ by centrifugation $(2,000 \times g, 10 \mathrm{~min})$, and resuspended with PBS $(100 \mathrm{mM}, \mathrm{pH}=7.8)$. The suspensions were sonicated on ice and then centrifuged $(15,000 \times g$, $10 \mathrm{~min})$. The supernatant was collected as the recombinant protein sample to measure the activity of CPR enzyme. The control eGFP protein was also expressed using the same method.

\section{CPR Activity and Cytotoxicity Assays}

Heterologously expressed AcCPR activity was determined by spectrophotometric measurement of the activity of NADPHcytochrome-c reduction according to the previous studies (Guengerich et al., 2009; Huang et al., 2015). Briefly, $166 \mu \mathrm{L}$ potassium phosphate buffer $(0.3 \mathrm{M}, \mathrm{pH}=7.7), 16 \mu \mathrm{L}$ protein sample, $16 \mu \mathrm{L} 0.5 \mathrm{mM}$ cytochrome-c solution (dliluted in potassium phosphate buffer, $10 \mathrm{mM}, \mathrm{pH}=7.7)$, and $2 \mu \mathrm{L}$ NADPH $(10 \mathrm{mM})$ were mixed thoroughly. Then, we used the Eon Microplate Spectrophotometer (BioTek, Winooski, VT, United States) to record the absorbance $(450,600 \mathrm{~nm}$, the slit width of the spectrophotometer was $1.0 \mathrm{~nm})$.

After a $24 \mathrm{~h}$ dsRNA treatment, 15 aphids were collected and homogenized on ice with $150 \mu \mathrm{L}$ potassium phosphate buffer $(0.3 \mathrm{M}, \mathrm{pH}=7.7)$. Then the homogenates were centrifuged at $10,000 \mathrm{~g}$ for $10 \mathrm{~min}$ at $4^{\circ} \mathrm{C}$ and the supernatants were used to test CPR activity using the same method as described above, and the absorbance at $550 \mathrm{~nm}$ was recorded for $5 \mathrm{~min}$. The amount $(\mathrm{nmol})$ of cytochrome $\mathrm{c}$ reduced per min at $27^{\circ} \mathrm{C}$ was defined as one unit (Guengerich et al., 2009). The protein content of the supernatants was measured by the Bradford method using a commercial kit (Beyotime Biotechnology, Shanghai, China).

The cytotoxic effect of abamectin on Sf9 cells was evaluated based on a previous study (Wang et al., 2015). For this test assay, $1 \times 10^{5}$ (about $500 \mu \mathrm{L}$ ) infected cells were incubated at $27^{\circ} \mathrm{C}$ for $24 \mathrm{~h}$ in a 24 well plate. Then, $10 \mu \mathrm{L}$ abamectin at different concentrations $(0.625,1.25,2.5,5,10 \mu \mathrm{g} / \mathrm{mL})$ was added into each well followed by a $24 \mathrm{~h}$ incubation. After incubation, the medium in wells was replaced with $220 \mu \mathrm{L}$ 3-(4,5-dimethyl-2-yl)-2,5-diphenyltetrazolium bromide (MTT) $(20 \mu \mathrm{L}$ MTT solution mixed with $200 \mu \mathrm{L}$ fresh medium). After a $4 \mathrm{~h}$ incubation, the medium with MTT was replaced with $300 \mu \mathrm{L}$ dimethyl sulfoxide. Finally, we measured the absorbance of dimethyl sulfoxide solution at $490 \mathrm{~nm}$ with the spectrophotometer. The percentage of viable cells relative to cells treated with acetone was calculated as cell viability. In this section, each treatment had four replicates.

\section{Western Blots}

The 12\% TGX Stain-Free polyacrylamide gels (Bio-Rad) were used to separate the macromolecules of each protein sample (AcCPR and eGFP). Then Trans-Blot ${ }^{\circledR}$ Turbo $^{\text {TM }}$ RTA Mini PVDF Transfer Kit (Bio-Rad) was used to transfer the separated proteins onto a PVDF membrane. After blocking, an overnight-incubation in His tag primary antibodies (Beyotime Biotechnology) at $4^{\circ} \mathrm{C}$ was followed. Then, the His tag primary antibodies were removed, and the horseradish peroxidase (HRP)conjugated secondary antibodies (Beyotime Biotechnology) were used to incubate the membrane. Finally, the blotted membrane was imaged after an incubation with Clarity Western ECL Substrate (Bio-Rad) using the ChemiDoc XRS+system (Bio-Rad).

\section{Statistical Analysis}

One-way analysis of variance (ANOVA) was used to test the differences in expression levels of $A c C P R$ among developmental stages and among various tissues, and the significance for the means were separated by Tukey's test $(P<0.05)$. The significance of the difference between two groups was determined by independent samples $t$-tests $(P<0.05)$. All the statistical analyses were performed with SPSS 20.0 for Windows (IBM, Chicago, IL, United States). 


\section{RESULTS}

\section{Cloning and Sequence Analysis of AcCPR}

The full-length ORF of $A c C P R$ was obtained from the transcriptome of $A$. citricidus. The AcCPR protein with 681 amino acid residues was encoded by 2,046 bp cDNA (GenBank accession no. MG807883). The predicted isoelectric point of this deduced protein was 5.33 with a predicted molecular weight of $77.7 \mathrm{kDa}$. There was no signal peptide, but a membrane anchor was found in the N-terminal region of AcCPR. It contained a hydrophobic transmembrane motif (20I-39Y: ISALDIALFIVIITVAYFWY), which helps to locate AcCPR on the endoplasmic reticulum. An alignment of AcCPR amino acid sequence revealed that it shared high amino acid identities with CPRs in other insects, including Acyrthosiphon pisum (96.6\%), Drosophila melanogaster (62.6\%), Tribolium castaneum (62.3\%), Apis mellifera (60.8\%), and Plutella xylostella (59.0\%). Furthermore, the AcCPR protein possessed several characteristic structural features (Figure 1). The key conserved domains of CPR proteins existed across different insect species, including the FMN-, FAD- (three residues R457, Y459, and S456 in this domain), and NADP-binding domains. In addition, four catalytic residues (S460, C633, D678, and W680) in the conserved active sites were also verified.

\section{Phylogenetic Analysis With Insect CPRs}

A phylogenetic analysis of AcCPR with 29 other CPR sequences from dipteran, coleopteran, lepidopteran, hymenopteran, and hemipteran insects was performed using MEGA 6.0 (Figure 2). The phylogenetic tree showed that CPRs from different insect species can be clearly separated and the CPRs from the same insect orders were grouped in the same branch. AcCPR was grouped in the branch composed of the CPRs of hemipteran insects, including A. pisum, Nilaparvata lugens, Cimex lectularius, and Bemisia tabaci, indicating a close evolutionary relationship between AcCPR and other CPRs in the hemipterans.

\section{Expression Patterns of AcCPR}

The expression patterns of $A c C P R$ at different developmental stages and in various tissues were determined using RT-qPCR (Figure 3). AcCPR was expressed at all the tested developmental stages of $A$. citricidus. The lowest $A c C P R$ mRNA level was detected in the third instar nymphs, and it increased from third instar nymphs to adults. The adult aphids (both apterous and alate aphids) had the highest expression levels of $A c C P R$, which suggests that $A c C P R$ may play an important role in the adult stage. Among the various tested tissues in adults, the highest mRNA expression was found in gut, while lower expression levels were detected in the central nervous system, embryo, fat body, integument, and salivary glands.

\section{Sensitivity to Abamectin After AcCPR Knockdown}

The aphids feeding of $d s C P R$ specifically decreased the expression of $A c C P R$ by $84 \%$ compared with the $d s G F P$ control (Figure 4).
Compared with the counterparts in $d s G F P$-treated and PBStreated aphids, the CPR activity of $d s C P R$-treated $A$. citricidus decreased by 41.8 and $45.4 \%$, respectively (Supplementary Figure S3). Additionally, knockdown of $A c C P R$ in the adult $A$. citricidus increased the sensitivity to abamectin exposure significantly. In detail, when treated with $2.5 \mathrm{mg} / \mathrm{L}$ abamectin, $78.8 \%$ of $A c C P R$-knockdown aphids died and it was a significantly higher mortality than the counterparts of the controls (52.5\% for PBS and 54.2\% for $d s G F P$, Figure 4). Thus, knockdown of $A c C P R$ exhibited an impact on the resistance of A. citricidus to abamectin.

\section{Heterologous Expression of AcCPR and Cytotoxicity Assay}

A baculoviral system was used to functionally analyze the AcCPR protein in insect cells. A recombinant AcCPR baculovirus stock was produced and transfected into Sf9 cells. Then, the AcCPR fusion protein $(6 \times$ His-tagged $)$ was expressed and verified by Western blot (Supplementary Figure S2). The spectral scanning of AcCPR microsomes showed a distinct peak at $550 \mathrm{~nm}$, which indicated that the AcCPR protein heterologously expressed in Sf9 cells had a high activity of cytochrome-c reduction (Figure 5).

Based on the successful expression of AcCPR protein with high activity of cytochrome-c reduction in vitro, we used the MTT assay to investigate the cytotoxicity effect of abamectin against AcCPR-expressing Sf9 cells. Normalized with acetonetreated cells, the viability of the cells treated by different abamectin concentration was calculated. Compared with the eGFP-expressing Sf9 control cells, the AcCPR-expressed cells exhibited a significantly higher viability than the eGFP-expressed cells at different concentrations of abamectin (Figure 5).

\section{DISCUSSION}

Insect P450s play essential roles in insecticide resistance and the detoxification of exogenous compounds. The electron transferring from NADPH to all the microsomal cytochromes P450s was catalyzed by a membrane-bound protein CPR. It has an indispensable role in the CYP/CPR system and is a restricting factor for the $\mathrm{P} 450$ activity in the metabolism of both endogenous and exogenous compounds including insecticides. Thus, further studies on the functions of insect CPRs will enrich the understanding of the mechanism responsible for insecticide resistance and promote the process of identification of new insecticide targets. In this study, the full-length ORF of the $C P R$ gene from $A$. citricidus was identified (AcCPR). The AcCPR protein, with 679 amino acids, shares a high similarity to other CPR proteins, like those of A. pisum, D. melanogaster, and Anopheles gambiae. The phylogenetic analysis showed that $A c C P R$ was clustered in the branch containing hemipterans. Structural prediction indicated that the AcCPR protein contains all the conserved CPR structural features, including an $\mathrm{N}$-terminal membrane anchor, FMN-, FAD-, and NADP-binding domains. The hydrophobic N-terminal membrane anchor attaches CPR to the endoplasmic reticulum's membrane and orients the remaining part of the $\mathrm{CPR}$ face on the cytoplasmic 

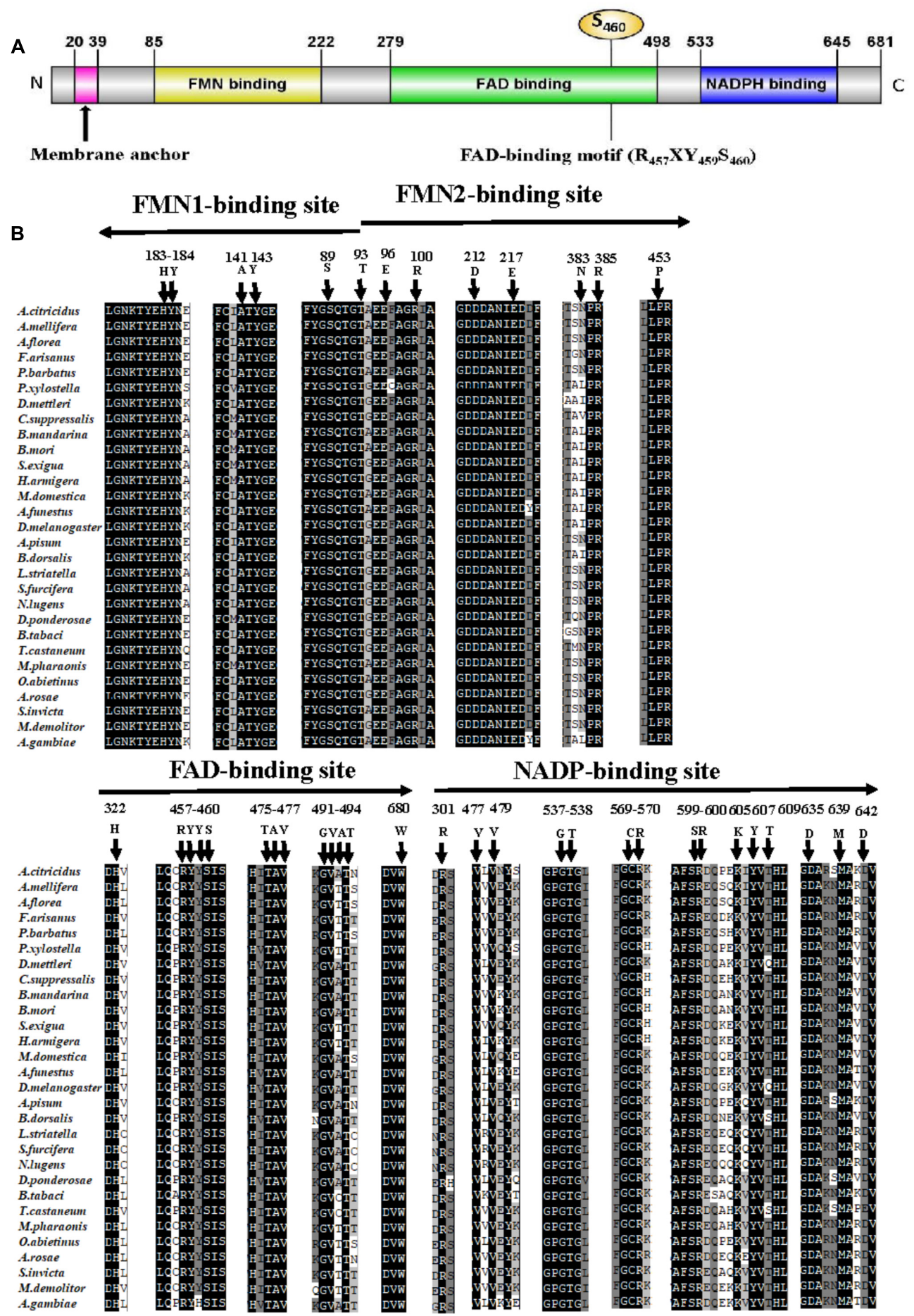

FIGURE 1 | Sequence analysis of the AcCPR protein. Schematic presentation of AcCPR. (A) Membrane anchor, FMN-, FAD-, and NADP-binding domains and the FAD-binding motif (R457, Y459, and S460) were showed. (B) Alignment of FMN-, FAD-, and NADP-binding sites in insect CPRs. Arrows show the direction from the $\mathrm{N}$-terminus to the $\mathrm{C}$-terminus. All CPR amino acid sequences were downloaded from GenBank (the accession numbers and species names are listed in Supplementary Table S2).

side together with the microsomal P450s. This is an indispensable structure for CPR to catalyze the electron transferring to P450s (Laursen et al., 2011). The N-terminus of the CPR protein is the FMN-binding domain containing two binding sites FMN1 and FMN2, and the FAD domain is connected to the FMN domain through a flexible loop. This flexible loop domain 

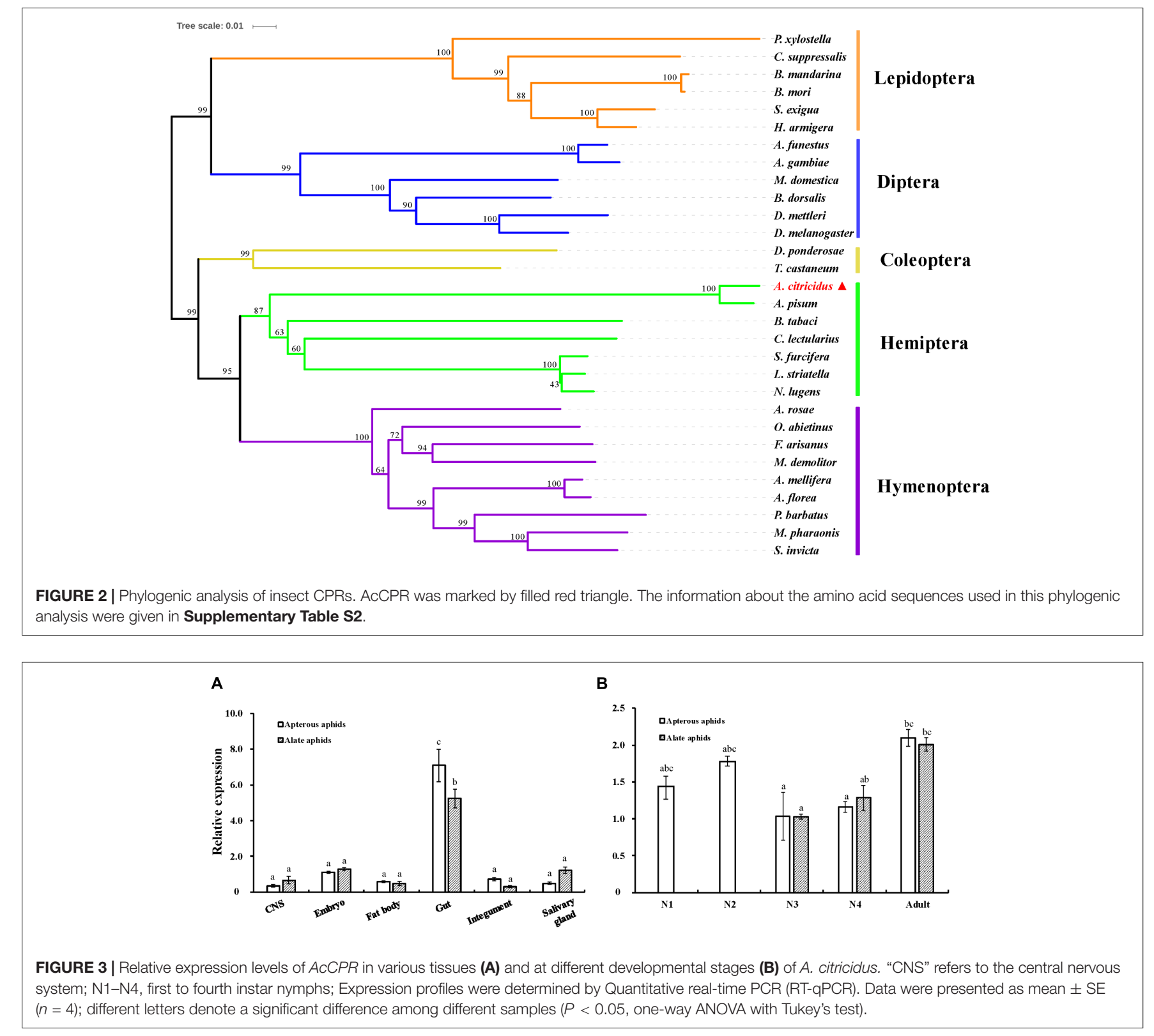

enhances conformational changes in the FMN domain to enable interactions with a variety of P450s (Laursen et al., 2011). Moreover, the conserved catalytic residues (S460, C633, D678, and W680) were found and considered as crucial active sites of the hydride transfer reaction.

P450s catalyze various metabolic reactions during the insect life cycle and in different tissues. The catalytic activities of $\mathrm{P} 450$ s depend on the electrons transferred by the redox partner of P450s, CPR, from NADPH. Therefore, the CPR level can reflect the $\mathrm{P} 450$ activity. The $C P R$ level in A. citricidus was relatively higher in the early nymphal and adult stages but was lower in third and fourth instar nymphs. AcCPR was expressed in different levels at different stages, indicating that $A C C P R$ might be involved in insect developmental processes by mediating the synthesis of 20-hydroxyecdysone driven by insect Halloween P450 enzymes. This mRNA expression pattern was similar to that of CPRs in other hemipteran insects, like L. striatellus (LsCPR) (Zhang et al., 2016) and $N$. lugens (NlCPR) (Liu et al., 2015). Such similar expression patterns in hemipteran insects across developmental stages suggest that CPR may have conserved functions in insect development.

$A c C P R$ mRNA was also detected in various tissues. The $A c C P R$ mRNA quantity was significantly higher in the gut than in other tissues. Among insects, CPRs present various expression patterns across tissues and the tissue distribution of genes can give us some clues about their functions. In D. melanogaster and Mamestra brassicae, CPRs are highly expressed in antennae and enhanced their odorant clearance capabilities in insect (Hovemann and Al, 1997; Maïbèche-Coisne et al., 2005). Similar to our results, 

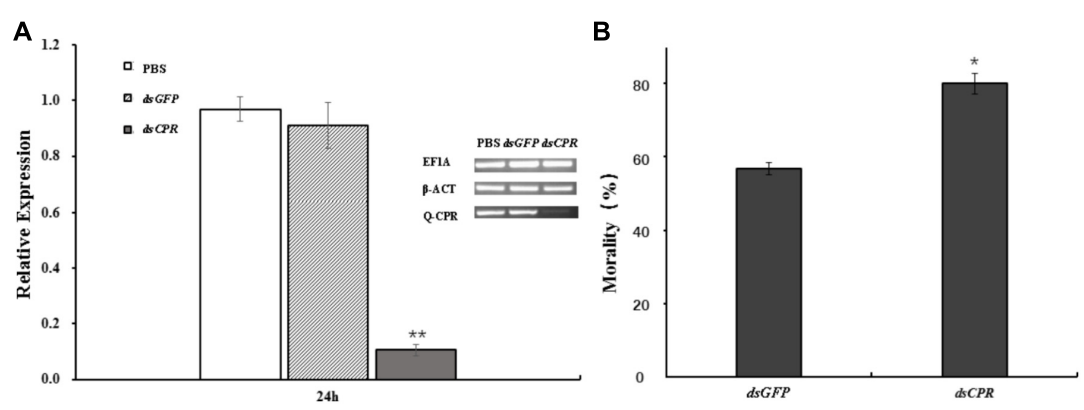

FIGURE 4 | The effect of RNA interference. (A) The mRNA levels of AcCPR after dsRNA feeding was evaluated by RT-qPCR. A. citricidus elongation factor-1 alpha $(E F 1 \alpha)$ and beta actin $(\beta$-act) were used as internal controls. Brightness of electrophoretic bands also showed the expression of AcCPR (Q-CPR) and internal control genes (EF1 $\alpha$ and $\beta$-ACT). (B) The resistance of the aphids to abamectin after AcCPR silencing. PBS, aphids feeding with PBS; dsGFP, aphids feeding with dsRNA against green fluorescent protein; dsCPR, aphids feeding with dsRNA against $A c C P R$. The data are the mean $\pm \mathrm{SE}$ of four biological repeats. One asterisk on the error bar indicates significant differences $(P<0.05)$ and two asterisks indicate extremely significant difference $(P<0.01)$.
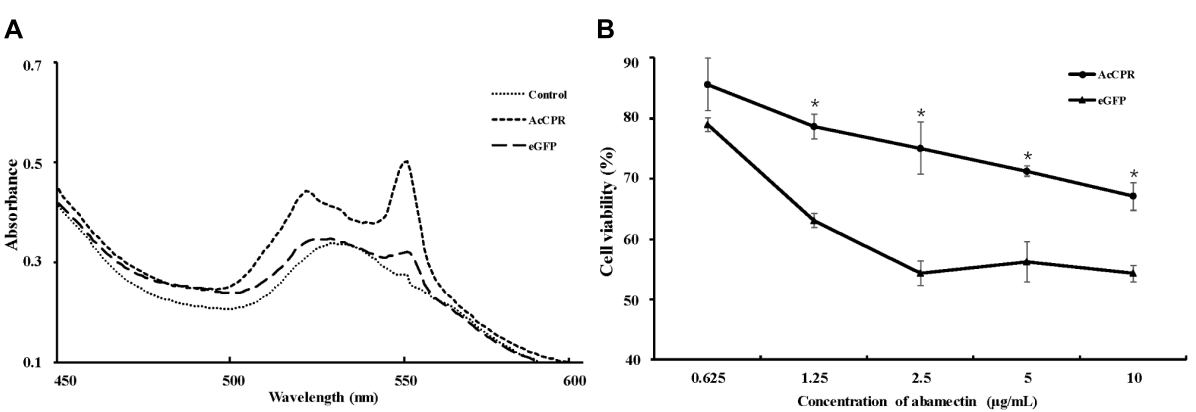

FIGURE 5 | Activity of AcCPR expressed in Sf9 cells measured by cytochrome-c reduction (A) and viability of cells to abamectin (B). Control, cell-free extracts of Sf9 cells; eGFP, cell-free extracts of eGFP-expressed Sf9 cells; AcCPR, cell-free extracts of AcCPR-expressed Sf9 cells. One asterisk on the error bar indicates significant differences $(P<0.05)$.

the CPR in Helicoverpa armigera expressed a high transcript level in the midgut. Both NlCPR in N. lugens and $L s C P R$ in L. striatellus were present at higher levels in the abdomen than those in other body parts. In general, the above three CPRs were involved in xenobiotic metabolism and the development of insecticide resistance (Liu et al., 2015; Zhang et al., 2016). Overexpression levels of $C P R s$ respond significantly to insecticide resistance. For instance, the $C P R$ transcripts were significantly overexpressed in a fenpropathrin-resistant strain (3.12-fold) of Tetranychus cinnabarinus (Li et al., 2015) and isoprocarbresistant (3.74-fold) strain of Rhopalosiphum padi (Wang et al., 2016), respectively. In our study, we also detected the $A c C P R$ mRNA level in a relatively abamectin tolerant population (AY) collected from Anyue County, Sichuan Province, China, and this population had a relative higher CPR expression level than the stock population (2.21-fold, Supplementary Figure S1). Many P450 genes are overexpressed 10-fold higher in insecticideresistant strains than their counterparts in insecticide-susceptible strains, whereas the degree of $C P R$ upregulation was not large $(<5$-fold). Previous studies have indicated that several P450s can be served by a single CPR, and many hypotheses support this idea; for instance, four P450s form a functional "cluster" or oligomer and then served by a single CPR. Also, increased affinity levels of P450 dimers with CPR facilitated a single
CPR to serve more P450s (Peterson et al., 1976; Backes et al., 1998; Davydov, 2011). Thus, just a small quantity of CPR can meet the electron requirements of a mass of P450s. That means a small change in CPR may exhibit great influences on $\mathrm{P} 450$ s, indicating that $\mathrm{CPR}$ is a key limiting factor of P450 enzyme activity. This also explains the smaller change in CPR expression relative to those of P450s in insecticideresistant strains. The overexpression of $\mathrm{P} 450$ genes enhances the detoxification of insecticides and the increased metabolic activity requires an enhanced rate of electron transfer catalyzed by CPRs. Thus, the knockdown of CPRs can result in the increased susceptibility to insecticides. This phenomenon has been found in many insects, including $N$. lugens (Liu et al., 2015), L. striatellus (Zhang et al., 2016), and B. dorsalis (Huang et al., 2015), as well in our insect of interest, A. citricidus, and most researchers support the point that knocking down of CPR reduced the P450 activity and then increased the resistance to insecticides.

Heterologous expression systems can efficiently investigate specific genes' functions. In D. melanogaster, a heterologously expressed insect-specific P450 CYP4G1 was found to be an oxidative decarbonylase and functions in cuticular hydrocarbon biosynthesis (Yue et al., 2012). This system was also widely used in the research on insecticide resistance mechanisms, including 
the report in which CYP392A16 in Tetranychus urticae catalyzed the hydroxylation of abamectin (Riga et al., 2014). In the present study, we overexpressed AcCPR protein in Sf9 cells using the Bac-to-Bac baculovirus system, in combination with the MTT cytotoxicity assay. We found that the AcCPR-overexpressing cells were significantly more viable when treated with abamectin than the control cells (eGFP-expressing cells). Previous studies reported that insect CPRs were related to resistance of many types of insecticides such as pyrethroids (beta-cypermethrin) (Liu et al., 2015), organophosphates (malathion) (Huang et al., 2015), carbamates (carbaryl) (Zhang et al., 2017), and insect growth regulators (buprofezin) (Zhang et al., 2016). However, the relationship between insect CPR and avermectin subfamily is lacking. As a member of avermectin, abamectin is widely used to control insect and mite pests including $A$. citricidus and Panonychus citri, and it was found to interact with specific gamma-aminobutyric acid (GABA)-sensitive chloride channels and glutamate-gated chloride channels in nematodes and arthropods (Schaeffer and Haines, 1989; Lynagh and Lynch, 2012). However, some non-target cells can be affected by abamectin. A novel mode of action of abamectin can explain the change in the insect cells' viability when treated with abamectin. It was reported that abamectin induced apoptosis to kill the insect Sf9 cells (Huang et al., 2011). When treated with abamectin, cytochrome-c, an important apoptosis-induced death effector also the substrate of CPR enzyme, was released from mitochondria into the cytosol during apoptosis when exposed to abamectin (Huang et al., 2011). When AcCPR was overexpressed in Sf9 cells, the cells showed a higher viability. Therefore, AcCPR was probably involved in the progress of apoptosis. The overexpressed AcCPR may act as competitive inhibitor to slow down the process of cell death. Similar mechanisms have been found in two citrus pest mites, T. urticae (Lümmen, 2007) and P. citri (Leeuwen et al., 2011). Bifenazate is a neurotoxin that acts on the postsynaptic GABA aminobutyric acid receptor. However, studies on these mites suggested an alternative mode in which bifenazate acts as a cytochrome-b ubiquinol oxidation-pocket inhibitor of mitochondrial complex III, and cytochrome-b ubiquinol oxidation-pocket mutations have been proved to be related with the resistance trait in mites. Similarly, once AcCPR acted as a kind of competitive inhibitor of the apoptosis inducer, it may enhance the tolerance capacity of insect cells to abamectin. Although no data are available to prove whether CPR acts as a high effective inhibitor, it may be a new perspective into the action mode of CPR protein in the development of resistance to insecticides.

\section{REFERENCES}

Backes, W. L., Batie, C. J., and Cawley, G. F. (1998). Interactions among P450 enzymes when combined in reconstituted systems: formation of a 2B4$1 \mathrm{~A} 2$ complex with a high affinity for NADPH-cytochrome $\mathrm{P} 450$ reductase. Biochemistry 37, 12852-12859. doi: 10.1021/bi980674a

Burg, R. W., Miller, B. M., Baker, E. E., Birnbaum, J., Currie, S. A., Hartman, R., et al. (1979). Avermectins, new family of potent anthelmintic agents: producing organism and fermentation. Antimicrob. Agents Chemother. 15, 361-367. doi: 10.1128/AAC.15.3.361

\section{CONCLUSION}

In conclusion, this study provides some basic molecular information of $A c C P R$ in $A$. citricidus. RNAi through feeding of dsRNA could efficiently silence the mRNA expression of $A c C P R$, decrease the activity of CPR, and enhance the resistance of $A$. citricidus to abamectin. Additionally, overexpression of AcCPR in Sf9 cells led to a higher cell viability upon abamectin treatment. This work expands our understanding of the important physiological role of insect CPR in xenobiotics detoxification and resistance development. Further research is needed to explore the essential role of the $A c C P R$ in CYPsmediated detoxification of insecticides and to test cell death by apoptosis.

\section{ETHICS STATEMENT}

The research project was conducted on invertebrate species that were not subjected to any specific ethical issue or legislation.

\section{AUTHOR CONTRIBUTIONS}

T-XJ, WD, D-DW, and J-JW designed the research and wrote the paper. T-XJ performed all the experiments with the help of YT, B-YD, WD, and D-DW. J-JW provided the materials. T-XJ and YT analyzed the data.

\section{FUNDING}

This work was financially supported by the National Natural Science Foundation (31672049), National Key R\&D Program of China (2016YFC1200600), the Fundamental Research Funds for the Central Universities (XDJK2017A014) of China, Funds from Chongqing Science and Technology Commission (cstc2017shmszx-xdny0031), and the earmarked fund for the Modern Agro-industry (Citrus) Technology Research System (CARS-26).

\section{SUPPLEMENTARY MATERIAL}

The Supplementary Material for this article can be found online at: https://www.frontiersin.org/articles/10.3389/fphys. 2018.00986/full\#supplementary-material

Davydov, D. R. (2011). Microsomal monooxygenase as a multienzyme system: the role of P450-P450 interactions. Expert Opin. Drug Metab. Toxicol. 7, 543-558. doi: 10.1517/17425255.2011.562194

Ding, B. Y., Shang, F., Zhang, Q., Xiong, Y., Yang, Q., Niu, J. Z., et al. (2017). Silencing of two insulin receptor genes disrupts nymph-adult transition of alate brown citrus aphid. Int. J. Mol. Sci. 18:E357. doi: 10.3390/ijms18020357

Feyereisen, R. (1999). Insect P450 enzymes. Annu. Rev. Entomol. 44, 507-533. doi: 10.1146/annurev.ento.44.1.507

Guengerich, F. P., Martin, M. V., Sohl, C. D., and Cheng, Q. (2009). Measurement of cytochrome P450 and NADPH-cytochrome 
P450 reductase. Nat. Protoc. 4, 1245-1251. doi: 10.1038/nprot.20 09.121

Hellemans, J., Mortier, G., Paepe, A. D., Speleman, F., and Vandesompele, J. (2007). qBase relative quantification framework and software for management and automated analysis of real-time quantitative PCR data. Genome Biol. 8:R19. doi: 10.1186/gb-2007-8-2-r19

Hovemann, B. T., and Al, E. (1997). Drosophila melanogaster NADPHcytochrome P450 oxidoreductase: pronounced expression in antennae may be related to odorant clearance. Gene 189, 213-219. doi: 10.1016/S0378-1119(96) 00851-7

Huang, J. F., Tian, M., Lv, C. J., Li, H. Y., Muhammad, R. U. H., and Zhong, G. H. (2011). Preliminary studies on induction of apoptosis by abamectin in Spodoptera frugiperda (Sf9) cell line. Pestic. Biochem. Physiol. 100, 256-263. doi: 10.1016/j.pestbp.2011.04.010

Huang, Y., Lu, X. P., Wang, L. L., Wei, D., Feng, Z. J., Zhang, Q., et al. (2015). Functional characterization of NADPH-cytochrome P450 reductase from Bactrocera dorsalis: possible involvement in susceptibility to malathion. Sci. Rep. 5:18394. doi: 10.1038/srep18394

Hunter, W. B., Dang, P. M., Bausher, M. G., Chaparro, J. X., Mckendree, W. Jr., et al. (2003). Aphid biology: expressed genes from alate Toxoptera citricida, the brown citrus aphid. J. Insect Sci. 3:23.

Lasota, J. A., and Dybas, R. A. (1991). Avermectins, a novel class of compounds: implications for use in arthropod pest control. Annu. Rev. Entomol. 36, 91-117. doi: 10.1146/annurev.en.36.010191.000515

Laursen, T., Jensen, K., and Møller, B. L. (2011). Conformational changes of the NADPH-dependent cytochrome P450 reductase in the course of electron transfer to cytochromes P450. Biochim. Biophys. Acta 1814, 132-138. doi: 10.1016/j.bbapap.2010.07.003

Leeuwen, T. V., Nieuwenhuyse, P. V., Vanholme, B., Dermauw, W., Nauen, R., and Tirry, L. (2011). Parallel evolution of cytochrome b mediated bifenazate resistance in the citrus red mite Panonychus citri. Insect Mol. Biol. 20, 135-140. doi: 10.1111/j.1365-2583.2010.01040.x

Li, S., Zhang, J., Shen, G., Xu, Z., Peng, W., Zhang, Y., et al. (2015). Silencing NADPH-cytochrome $\mathrm{P} 450$ reductase results in reduced acaricide resistance in Tetranychus cinnabarinus (Boisduval). Sci. Rep. 5:15581. doi: 10.1038/srep 15581

Liao, C. Y., Xia, W. K., Feng, Y. C., Li, G., Liu, H., Dou, W., et al. (2016). Characterization and functional analysis of a novel glutathione S-transferase gene potentially associated with the abamectin resistance in Panonychus citri (McGregor). Pestic. Biochem. Physiol. 132, 72-80. doi: 10.1016/j.pestbp.2015.11. 002

Liu, S., Liang, Q. M., Zhou, W. W., Jiang, Y. D., Zhu, Q. Z., Yu, H., et al. (2015). RNA interference of NADPH-cytochrome P450 reductase of the rice brown planthopper, Nilaparvata lugens, increases susceptibility to insecticides. Pest. Manag. Sci. 71, 32-39. doi: 10.1002/ps.3760

Lümmen, P. (2007). Mitochondrial Electron Transport Complexes as Biochemical Target Sites for Insecticides and Acaricids. Berlin: Springer. doi: 10.1007/978-3540-46907-0_8

Lynagh, T., and Lynch, J. W. (2012). Ivermectin binding sites in human and invertebrate Cys-loop receptors. Trends Pharmacol. Sci. 33, 432-441. doi: 10.1016/j.tips.2012.05.002

Maïbèche-Coisne, M., Merlin, C., François, M. C., Porcheron, P., and JacquinJoly, E. (2005). P450 and P450 reductase cDNAs from the moth Mamestra brassicae: cloning and expression patterns in male antennae. Gene 346, 195-203. doi: 10.1016/j.gene.2004.11.010

Moreno, P., Ambrós, S., Albiach-Martí, M. R., Guerri, J., and Peña, L. (2008). Citrus tristeza virus: a pathogen that changed the course of the citrus industry. Mol. Plant Pathol. 9, 251-268. doi: 10.1111/j.1364-3703.2007.00455.x

Niu, G., Zhao, S., Wang, L., Dong, W., Liu, L., and He, Y. (2017). Structure of the Arabidopsis thaliana NADPH-cytochrome P450 reductase 2 (ATR2) provides insight into its function. FEBS J. 284, 754-765. doi: 10.1111/febs.14017

Paine, M. J. I., Scrutton, N. S., Munro, A. W., Gutierrez, A., Roberts, G. C. K., and Wolf, C. R. (2005). Electron Transfer Partners of Cytochrome. New York, NY: Springer, 450. doi: 10.1007/0-387-27447-2_4
Peterson, J. A., Ebel, R. E., O’Keeffe, D. H., Matsubara, T., and Estabrook, R. W. (1976). Temperature dependence of cytochrome P-450 reduction. A model for NADPH-cytochrome P-450 reductase: cytochrome P-450 interaction. J. Biol. Chem. 251, 4010-4016. doi: 10.1016/0003-9861(76)90 099-0

Riga, M., Tsakireli, D., Ilias, A., Morou, E., Myridakis, A., Stephanou, E. G., et al. (2014). Abamectin is metabolized by CYP392A16, a cytochrome P450 associated with high levels of acaricide resistance in Tetranychus urticae. Insect Biochem. Mol. Biol. 46, 43-53. doi: 10.1016/j.ibmb.2014. 01.006

Schaeffer, J. M., and Haines, H. W. (1989). Avermectin binding in Caenorhabditis elegans. A two-state model for the avermectin binding site. Biochem. Pharmacol. 38, 2329-2338. doi: 10.1016/0006-2952(89)90473-5

Shang, F., Niu, J. Z., Ding, B. Y., Zhang, Q., Ye, C., Zhang, W., et al. (2017). Vitellogenin and its receptor play essential roles in the development and reproduction of the brown citrus aphid, Aphis (Toxoptera) citricidus. Insect Mol. Biol. 27, 221-233. doi: 10.1111/imb.12366

Shang, F., Wei, D. D., Jiang, X. Z., Wei, D., Shen, G. M., Feng, Y. C., et al. (2015). Reference gene validation for quantitative PCR under various biotic and abiotic stress conditions in Toxoptera citricida (Hemiptera. Aphidiae). J. Econ. Entomol. 108, 2040-2047. doi: 10.1093/jee/tov184

Shoop, W. L., Mrozik, H., and Fisher, M. H. (1995). Structure and activity of avermectins and milbemycins in animal health. Vet. Parasitol. 59, 139-156. doi: 10.1016/0304-4017(94)00743-V

Tamura, K., Stecher, G., Peterson, D., Filipski, A., and Kumar, S. (2013). MEGA6: molecular evolutionary genetics analysis Version 6.0. Mol. Biol. Evol. 30, 2725-2729. doi: 10.1093/molbev/mst197

Wang, K., Peng, X., Zuo, Y., Li, Y., and Chen, M. (2016). Molecular cloning, expression pattern and polymorphisms of NADPH-Cytochrome P450 reductase in the bird cherry-oat aphid Rhopalosiphum padi (L.). PLoS One 11:e0154633. doi: 10.1371/journal.pone.0154633

Wang, L. L., Huang, Y., Lu, X. P., Jiang, X. Z., Smagghe, G., Feng, Z. J., et al. (2015). Overexpression of two $\alpha$-esterase genes mediates metabolic resistance to malathion in the oriental fruit fly, Bactrocera dorsalis (Hendel). Insect Mol. Biol. 24, 467-479. doi: 10.1111/imb.12173

Wang, M., Roberts, D. L., Paschke, R., Shea, T. M., Masters, B. S., and Kim, J. J. (1997). Three-dimensional structure of NADPH-cytochrome P450 reductase: prototype for FMN- and FAD-containing enzymes. Proc. Natl. Acad. Sci. U.S.A. 94, 8411-8416. doi: 10.1073/pnas.94.16.8411

Yue, Q., Tittiger, C., Wicker-Thomas, C., Goff, G. L., Young, S., Wajnberg, E., et al. (2012). An insect-specific P450 oxidative decarbonylase for cuticular hydrocarbon biosynthesis. Proc. Natl. Acad. Sci. U.S.A. 109, 14858-14863. doi: 10.1073/pnas.1208650109

Zhang, X., Wang, J., Liu, J., Li, Y., Liu, X., Wu, H., et al. (2017). Knockdown of NADPH-cytochrome P450 reductase increases the susceptibility to carbaryl in the migratory locust, Locusta migratoria. Chemosphere 188, 517-524. doi: 10.1016/j.chemosphere.2017.08.157

Zhang, Y., Wang, Y., Wang, L., Yao, J., Guo, H., and Fang, J. (2016). Knockdown of NADPH-cytochrome $\mathrm{P} 450$ reductase results in reduced resistance to buprofezin in the small brown planthopper, Laodelphax striatellus (fallen). Pestic. Biochem. Physiol. 127, 21-27. doi: 10.1016/j.pestbp.2015. 08.006

Conflict of Interest Statement: The authors declare that the research was conducted in the absence of any commercial or financial relationships that could be construed as a potential conflict of interest.

Copyright (c) 2018 Jing, Tan, Ding, Dou, Wei and Wang. This is an open-access article distributed under the terms of the Creative Commons Attribution License (CC BY). The use, distribution or reproduction in other forums is permitted, provided the original author(s) and the copyright owner(s) are credited and that the original publication in this journal is cited, in accordance with accepted academic practice. No use, distribution or reproduction is permitted which does not comply with these terms. 